\title{
Recipijenti pučke književnosti kao polazište za razumijevanje pučke poetike
}

\author{
JOSIPA TOMAŠIĆ \\ Odsjek za kroatistiku, \\ Filozofski fakultet Sveučilišta u Zagrebu
}

\begin{abstract}
U radu se problematizira pučko s posebnim osvrtom na recipijenta pučke književnosti. Polazi se od teze da pučkost kao svojstvo nije nužno upisana u sam tekst, nego se realizira u dinamici čitanja/slušanja teksta, odnosno u dijalogu između teksta i njegova recipijenta koji pripada tzv. nepovlaštenim čitateljima. Promatra se društvena struktura pučkoga čitatelja/slušatelja i razina estetske kondicioniranosti s kojom raspolaže, a koja definira strukturu pučkoga književnoga teksta i njegovu estetiku. Pristup pučkoj književnosti promatra se unutar dosadašnjih istraživanja hrvatske pučke književnosti s osobitim osvrtom na radove Divne Zečević u kojima su postavljeni temelji za daljnja istraživanja pučkoga književnoga fenomena.
\end{abstract}

Ključne riječi: pučka književnost, pučka poetika, recipijenti, popularni tekstovi, pučke knjižice, popularno prosvjetiteljstvo

\section{DOSADAŠNJA ISTRAŽIVANJA HRVATSKE PUČKE KNJIŽEVNOSTI: POSTAVLJANJE PROBLEMA}

Sustavno istraživanje pučke književnosti u hrvatskoj znanosti intenzivno započinje sedamdesetih godina 20. stoljeća radovima Divne Zečević. Ona se u hrvatskoj povijesti književnosti najsustavnije bavila pučkom književnosti proučavajući je na temelju građe pučkih kalendara i pjesmarica ${ }^{1} 18$. i

\footnotetext{
${ }^{1}$ Autorica im je posvetila i zasebne studije: Hrvatske pučke pjesmarice 19. stoljeća (Svjetovne i nabožne) (1988) i Pučko književno štivo u hrvatskim kalendarima prve polovice 19. stoljeća, 1. i 2. dio (1982) u kojima pokazuje sve specifičnosti pučkoga književnoga fenomena, od tematsko-motivske zaokupljenosti, binarnih opozicija u prezentiranju zbilje, sprege pouke i zabave do doživljaja povijesti i pučke koncepcije svijeta. Unutar njih problematizira pitanje didakticizma u književnosti, problem podjele na nabožnu i svjetovnu književnost te zaokupljenost činjeničnim u kalendarskome štivu. Na tragu Andrea Jollesa (Jednostavni oblici, 2000) pokazuje kako je duhovna zaokupljenost kalendarskoga štiva u činjeničnom, koje je podvrgnuto načelu izbora činjenica.
} 
19. stoljeća te u okviru proučavanja pučkih propovijedi i nabožnoga štiva. ${ }^{2}$ Legitimnost u okviru povijesti nacionalne književnosti pučka je književnost stekla izdanjem u ediciji Povijest hrvatske književnosti, knjiga 1 (1978), u kojoj se, uz teorijski i povijesni pregled usmene književnosti koji je napisala Maja Bošković-Stulli, donosi i pregled pučke književnosti autorice Divne Zečević naslovljen Pučki književni fenomen. ${ }^{3}$ Pučkoj književnosti kao trećemu književnomu fenomenu Zečević pristupa sustavno i znanstveno, problematizira odnos pučkoga i usmenoga (Zečević 1971; 1978: 480-487), ukazuje na specifičnosti pučkoga književnoga fenomena i poetičke zakonitosti koje ga oblikuju.

U knjizi Književnost na svakom koraku (1986) pristup pučkoj književnosti upotpunjuje spoznajom da se "fenomen pučke književnosti ne može odrediti samo, ili isključivo, karakterom teksta nego u odnosu teksta i potrošača" (Zečević 1986: 41) te svoje istraživanje usmjerava prema recipijentu, njegovim potrebama i zahtjevima te načinu kako doživljava i prima tekst. U kasnijim radovima interes usmjerava prema svakodnevici, pokazuje prisutnost pučkoga načina mišljenja u suvremenosti (vidi Zečević 1999) te pučko dovodi u blisku vezu s masovnim tiskom i popularnom književnosti.

Zečević pučko dovodi u vezu s književnim fenomenima s kojima je u doticaju, ali katkada izostaju jasni kriteriji vrednovanja pa se nedovoljno jasno razgraničavaju termini u doticaju, pučka i popularna književnost, odnosno pučko i trivijalno. ${ }^{4}$ Nedovoljno jasno razgraničenje proizlazi iz nejasnih granica jer se fenomeni prepleću i dodiruju, što u pojedinim slučajevima poprilično otežava jasno razgraničenje. Odnos pučkoga i popularnoga složeniji je u novijem vremenu kada se termini pučko i popularno često izjednačuju.

Važnost razumijevanja i razgraničenja književnih fenomena u odnosu na sve tri sastavnice književne komunikacije (autor, tekst i recipijent) ističe Pavao Pavličić (1987b) iznoseći tezu kako bi se uz pomoć triju navedenih komponenata, uvažavajući i sinkroniju i dijakroniju, moglo razgraničiti fenomene usmene, pučke i trivijalne književnosti. Pavličić izvrsno primjećuje kako je trivijalna književnost, a ne pučka, jedina prava konkurencija "viso-

\footnotetext{
${ }^{2}$ Problematikom pučkoga nabožnoga štiva bavila se Divna Zečević, uz brojne znanstvene radove, $\mathrm{u}$ knjizi Strah Božji: hrvatske pučke propovijedi 18. stoljeća (1993).

${ }^{3}$ Iako je uvrštavanje pučke književnosti u ediciju Povijest hrvatske književnosti pokazalo znanstvenu zrelost i spremnost hrvatske književne znanosti da rubnomu književnomu fenomenu posveti veliku pozornost, Josip Kekez zamjera što su se usmena i pučka književnost našle u istoj knjizi, osobito stoga što je mišljenja da hrvatska usmena književnost treba dobiti ravnopravan status u odnosu na pisanu književnost kojoj je uvijek prethodila, a ovakvo svrstavanje pokazuje još jednu koncepcijsku neprimjerenost (vidi Kekez 1998: 138).

${ }^{4}$ Isti je prigovor uputio Pavao Pavličić u osvrtu na knjigu Književnost na svakom koraku. Pavličić zamjera "nedovoljno jasno razgraničenje pučke i trivijalne literature: na trenutke se čini da ih autorica vidi kao jedan fenomen, a na trenutke opet kao da ih luči” (Pavličić 1987a: 249).
} 
koj" književnosti, naznačujući time poziciju koju pučka književnost zauzima u odnosu prema ostalim književnim fenomenima.

Dok Divna Zečević termine pučko i popularno izjednačuje, Maja Bošković-Stulli razdvaja pučko od popularnoga držeći kako "pučka književnost sociološki određena jednako kao i pučko štivo - ima svoja vlastita specifična svojstva u širem području popularne književnosti" (Bošković-Stulli 1983: 75). Pučku književnost autorica promatra u odnosu prema tzv. visokoj umjetničkoj književnosti i prema usmenoj književnosti detektirajući zone doticaja i prepletanja te zaključuje kako je "pučka književnost u većoj mjeri područje koje povezuje usmenu i pisanu umjetničku književnost, negoli međuprostor koji bi ih razdvajao" (Bošković-Stulli 1983: 63). Naslanjajući se na Rudolfa Schendu, određuje pučku književnost kao sociološki uvjetovan fenomen koji razvija vlastite specifičnosti unutar širega područja popularne književnosti.

Sasvim drukčiji pristup pučkome donosi Ivan Slamnig (1965) koji termin pučki koristi uz gradsku pjesmu. Kritiku Slamnigu uputila je Maja BoškovićStulli (1983: 113) ističući kako se mjerila po kojima se određuju specifičnosti pučkoga pjesništva ne bi mogla prihvatiti kao osnova za određivanje pojma pučke književnosti. Naravno, pripadnost gradskoj sredini kao važno obilježje pučke književnosti nije održivo kada se uzme u obzir ukupna pučka produkcija, jer pučku književnost ne možemo svesti isključivo na književnost gradskoga ili seoskoga tipa. U poglavlju "Pjesma kao faktor kolektivne svijesti" Slamnig donosi razmatranja o vezi pjesništva i određene zajednice naglašavajući kako svaki društveni sloj ima svoju književnost kao što ima i svoj jezik, odnosno "svaka grupa posjeduje zajedničku svijest, a svaka zajednička svijest nosi u sebi i svoju poeziju, svoju umjetnost, onako, kao što ima svoj govor" (Slamnig 1965: 13). Takvi uvidi računaju s čitateljem kao važnim faktorom i plodno su područje za promišljanje o pučkoj književnosti.

Pučkom se književnosti u okviru proučavanja nekanonskih i često marginaliziranih pisaca i rubnih književnih tema bavio Tomo Matić (vidi Matić 1951; 1994) iako ne kao teoretičar, nego prikupljanjem, proučavanjem i obradom izvora.

Suvremena hrvatska znanost pučkom književnom fenomenu ne pristupa sustavno. Njime se u znanstvenome radu, uz druge svoje znanstvene interese, bavi Milovan Tatarin, uglavnom u okviru analize kalendarskoga štiva (Tatarin 2006; 2007) i nabožne književnosti starijih razdoblja. ${ }^{5}$ Tatarinovi radovi daju uvide u strukturu pučkoga čitateljstva i vrijedan su doprinos proučavanju pučke književnosti.

${ }^{5}$ U knjizi Zaboravljena Oliva (1999) Tatarin donosi rasprave s temama iz starije hrvatske književnosti u kojima obrađuje nekanonske pisce kojima se svojevremeno bavio i Tomo Matić (1951). Iako problematiziranje pučkoga književnoga fenomena ovdje nije u prvome planu, njega se Tatarin dotiče obrađujući pojedine pisce i djela, na primjer Velikanovićeve, Tomikovićeve i Čevapovićeve nabožne drame, crkvena prikazanja, ili hagiografski motiv Olive kao jedan od najomiljenijih pučkih motiva. 
Ovdje je potrebno spomenuti i rad Nikole Crnkovića koji se pučkom književnosti bavi više sakupljački nego teorijski, iscrpno istražuje pašku pučku poetiku i lokalne paške pjesnike, ${ }^{6}$ donosi podatke iz biografije pjesnika i mjesta. Crnkoviću se može prigovoriti nedovoljnu teorijsku razradu, nejasno razlikovanje usmene i pučke književnosti jer on i tradicionalno usmeno pjesništvo naziva pučkim, s naznakom neautorsko pučko pjesništvo, za razliku od autorskoga kojemu posvećuje najveću pozornost.

Nakon Divne Zečević sustavnih istraživanja hrvatske pučke književnosti nema, čime se još uvijek marginalizirano područje pučke književnosti pokazuje kao istraživački izazov, kao plodno istraživačko područje koje zahtijeva znanstvenu i stručnu obradu.

\section{PUČKI RECIPIJENT: POLAZIŠTE ZA RAZUMIJEVANJE PUČKE POETIKE}

Pučka književnost zauzima međuprostor između usmene i umjetničke književnosti koji je Peter Burke (1991), oslanjajući se na Davida Macdonalda, odredio kao pojavu smještenu između male i velike tradicije iz kojih neprestano crpi, uz važnu napomenu o dvosmjernome procesu utjecaja između književnih fenomena (tradicija) koji su u doticaju. Tranzicijska pozicija pučke književnosti čini pučki književni fenomen ovisnim s jedne strane o djelokrugu usmenoga, a s druge strane pisanoga umjetničkoga stvaralaštva, što znatno određuje poetiku toga tipa književnosti.

Nadovezujući se na ranije uvide Pavla Pavličića (1987b) pokazalo se kako uloga i status autora i teksta u pučkoj književnosti čine pučki književni fenomen bliskim usmenoj književnosti, ali uz značajna udaljavanja od tradicionalne usmene književnosti, a razlike $u$ doživljavanju tih dviju književnih kategorija proizlaze iz različitih poetičkih odrednica (vidi Tomašić Jurić 2014: 27-37). Omjeravanje o relativno čvrste kategorije autora i teksta pomaže jasnijem određivanju pučkoga književnoga fenomena u odnosu na usmenu i umjetničku književnost, ali za preciznije definiranje pučke književnosti potrebno je poći od pučkoga recipijenta, njegovih književno-estetskih zahtjeva, društvenoga sloja kojemu pripada i očekivanja koja ima od književnoga teksta.

${ }^{6}$ Uz Pašku pučku poetiku kao povijestni govor (2003) Crnković je objavio četverosveščanu Pažku pučku poetiku (sv. 1-3 objavljeni su 2011. godine, a sv. 4 objavljen je 2013. godine). Prva knjiga pod naslovom Pažka pučka poetika kao povjestni govor. Kolan i Novalja (2011) izmijenjeno je i dopunjeno izdanje Paške pučke poetike iz 2003. godine. 


\section{Pučki recipijent: društvena struktura čitateljstva}

Presudna uloga recipijenta za pučku književnost zahtijeva drukčiji pristup književnomu fenomenu, pristup koji se ne smije usredotočiti jedino na tekst, nego se mora promatrati u odnosu teksta i recipijenta. Pitanje komu su namijenjeni pučki književni tekstovi zahtijeva i odgovor na pitanje kakva je društvena struktura čitateljstva toga tipa književne produkcije. Hrvatska pučka knjiga ili knjiga za puk, kako se često imenuje taj tip književne produkcije, ne razlikuje se značajno od tipičnih knjiga toga tipa u ostatku Europe. Kao specifičnost hrvatske pučke knjige Aleksandar Stipčević izdvaja jezik koji je pučkoj knjizi velikim dijelom odredio regionalnu razumljivost (vidi Stipčević 2005: 170, 344-345).

Odabir narodnoga jezika nije, naravno, jedino mjerilo pučkosti jer u hrvatskoj književnosti, kao i u drugim europskim književnostima, djeluju autori koji pišu književna djela i na narodnome jeziku, a koja ne pripadaju sferi pučkoga. Narodni jezik pučke knjige podrazumijeva jeziku "prilagođen" sadržaj i ciljanoga recipijenta kojemu su odabrani sadržaji namijenjeni. Riječ je o širokoj čitateljskoj, u velikoj mjeri i slušateljskoj publici, slabo pismenoj ili polupismenoj, koja se pojavila na književnoj pozornici.

Važnosti novoga čitateljskoga sloja koji dolazi "odozdo" i postaje sve aktivniji sudionik društva i kojemu je potrebno ponuditi književnost koju može razumjeti, koja će ga oblikovati i prosvijetliti, vrlo su rano postali svjesni crkveni djelatnici te su počeli s prosvjećivanjem puka nudeći mu prilagođenu duhovnu literaturu (životopisi svetaca, molitvenici, katekizmi, pjesmarice i slično) ${ }^{7}$ (vidi Stipčević 2005: 171, 173, 334). Proizvodnja knjige za puk projekt je i takozvanoga popularnoga prosvjetiteljstva ${ }^{8}$ (eng. Popular Enlightenment, njem. Volksaufklärung). Tiskaju se članci, brošure, kalendari, almanasi, knjižice prilagođene potrebama običnoga puka. U 18. stoljeću prosvjećivanje je vezano uz proces prijelaza na kulturu pisma i nije usmjereno samo na prosvjećivanje pojedinca, nego na društvo u cjelini te kontrolu i uspostavu društvenih vrijednosti (vidi Knudsen 1996: 279-280). Osobito je u drugoj polovici 18. stoljeća osviještena važnost pisane riječi, knjige i čitanja, kao neupitnoga čimbenika društvenoga napretka. Vrijeme je to kada knjiga postaje "dijelom smišljene, programatske društvene akcije" (Stipčević

\footnotetext{
${ }^{7}$ Važno je spomenuti da je organizirana proizvodnja knjige za puk započela s reformacijom te kasnije, u drugome valu, s protureformacijom.

${ }^{8}$ Volksaufklärung se definira kao prosvjetiteljstvo usmjereno prema određenoj društvenoj klasi, prilagođeno potrebama te klase, i kao takvo ima svoja ograničenja. Ono je i oblik kontrole i "oblikovanja" puka upravo preko znanja, literature koja mu se nudi te je tako i politički upravljano: "Literatura popularnoga prosvjetiteljstva otkriva fragmentarnost političkih ideja 'običnih' ljudi i ‘sela'. [...] Možemo tvrditi da je popularno prosvjetiteljstvo bilo apolitično u svojim obrisima, ali politično u svojoj namjeri, jer su se pisci usredotočili na napredak i na kontrolu seoskoga stanovništva" (Knudsen 1996: 275-276).
} 
2005: 334-335). Društvena svijest o važnosti opismenjavanja širokoga sloja pučanstva omogućila je procvat takozvane knjige za puk.

Važnu društvenu funkciju prosvjećivanja puka i širenja čitateljske publike na hrvatskim su prostorima imali pučki kalendari (vidi Tatarin 2006, 2007). Kao praktična poučna knjiga kalendar je bio namijenjen širem čitateljskom sloju imajući pritom u vidu stupanj (ne)pismenosti svojih recipijenata, a svjesno odabrani tekstovi (od praktičnih savjeta o životu, preko stihovanih i proznih književnih uradaka) prilagođavani su mogućnostima i potrebama recipijenata i imali su u prvom redu utilitarnu funkciju. Pučka literatura imala je sličnu funkciju i u ostalim europskim zemljama. Leslie Shepard (1973: 110) donosi podatak da su broadside balade i pučke knjižice (chapbooks) ${ }^{9}$ imale značajnu ulogu u razvijanju čitateljskih navika običnih ljudi i njihovu okulturavanju.

Pojava nove publike, koju ovdje možemo nazvati pučkim čitateljskim slojem, zahtijevala je sadržaje prilagođene svojim mogućnostima. Usmjerenost na ciljanoga recipijenta, razvijena svijest o njegovim potrebama i mogućnostima, jedno je od istaknutijih obilježja pučkih tekstova. Pokušaj udovoljavanja potrebama recipijenata potvrđuje i posebna uređivačka politika francuske Bibliothèque Bleue koja je podržavala prilagođavanje tekstova (kraćenje, pojednostavljivanje, rezanje i ilustriranje) kako bi im osigurala čitanost unutar širih slojeva (vidi Chartier 2002: 52).

Pisci su pisali djela namijenjena puku iz različitih pobuda, a prosvjetiteljska motivacija, koju možemo primijetiti kod većine pučkih ili pučki orijentiranih pisaca, eksplicitno je izrečena u predgovorima njihovih tekstova (vidi Tomašić Jurić 2014: 88-96). Osim pučkih pisaca i nakladnici pučkih knjiga ističu brigu za dobrobit puka, odnosno za niže društvene slojeve. Literatura za puk, piše Stipčević, trebala je zadovoljiti društvenu ulogu odgajatelja puka, trebala mu je donijeti korisne savjete, poučiti ga zemljoradnji, odgoju djece, vjeri i kršćanskome moralu pa su razni dušobrižnici u tome pronašli svoje mjesto (vidi Stipčević 2008: 158-159). Naglašena izvanknjiževna funkcija težište je stavila na korisnost prije svega, a onda i na zabavu, razonodu, dok je estetska funkcija stavljena u drugi plan, ali nije zanemarena kako se često misli, nego je estetika prilagođena očekivanjima i mogućnostima recipijenata.

Potreba pučkih pisaca da svoja djela prilagode potrebama čitatelja, njihovim doživljajno-spoznajnim mogućnostima, ocrtava strukturu pučkoga čita-

${ }^{9}$ Chapbook (njem. Volksbücher) pučka je knjižica koja sadrži raznolike pučke vrlo popularne tekstove prilagođene svojim pretpostavljenim adresatima. "Pučke su knjižice (chapbooks) prepričavale stare romanse i bajke, donosile priče o davnim bitkama, prepričavale su praznovjerja i zagonetke, tumačile snove i proricale budućnost, pozivale grešnike na pokajanje ili jednostavno donosile šaljive priče. Te su jeftine knjižice bile literatura siromašnih ljudi i kao takve oblikovale su njihov pogled na život i njihovu filozofiju" (Shepard 1973: 26-28). 
teljstva: visoku razinu nepismenosti ${ }^{10}$ ili polupismenosti, pučki svjetonazor, stupanj estetske kondicioniranosti s kojom raspolažu. Imajući u vidu društvenu strukturu čitateljstva, raslojavanje čitateljske publike kojim postaje sve veći jaz između malobrojnih učenih ljudi koji mogu čitati umjetničku književnost i niskoobrazovanoga sloja seljaštva i siromašnoga građanstva koji nemaju pristup knjizi, pisci svjesno stvaraju knjigu za puk prilagođenu mogućnostima ciljanih recipijenata. Naravno, potpuno je drugo pitanje, i možda ovdje manje važno, jesu li ti pisci sebe smatrali pučkim piscima i jesu li uopće svoj rad doživljavali književnim. On je, u svakom slučaju, odgovarao književnim potrebama pučkoga čitatelja.

Problem pismenosti, kako vidimo, ne iscrpljuje se više u jednostavnoj opreci između pismenih i nepismenih jer se javlja novi čitateljski sloj kao posljedica raslojavanja hrvatske čitateljske publike, osobito u 19. stoljeću. Pristup književnoj recepciji mora računati na različite čitateljske sposobnosti, na različite čitateljske slojeve i čitateljske tradicije, jer o tome ovisi način čitanja i doživljavanja književnoga djela. Pritom moramo računati na različita očekivanja prisutna u praksi čitanja kod različitih društvenih slojeva jer o tim odlučujućim čimbenicima (čitateljskim sposobnostima, tradicijama, očekivanjima) ovisi pristup tekstu, način čitanja. Divna Zečević piše kako čitateljeva očekivanja i potrebe ne ovise jedino o njegovim sklonostima i životnoj dobi, već su oblikovane "stupnjem njegova obrazovanja i društvenog sloja, ili skupinom kojoj pripada" (Zečević 1986: 41).

Među recipijentima pučke književnosti i u 19. stoljeću još uvijek je znatan postotak nepismenih koji sadržaj knjige primaju isključivo usmenim putem. Stoga se prakticira tzv. glasno čitanje koje je funkcioniralo kao kohezivni čimbenik određene zajednice (Chartier 2002: 50). Glasno se čitanje zadržalo u mnogim ruralnim prostorima i u 20. stoljeću jer je još uvijek broj nepismenih i slabopismenih bio velik. ${ }^{11}$ Fenomen glasnoga čitanja kao posredovanja literarnih informacija, kada je posrednik informacije pismena osoba koja naglas čita nepismenoj zajednici, Rudolf Schenda označio je terminom polupismenost (semiliterate process), dok društvenu situaciju koja podrazumijeva ponavljanje sadržaja pročitanih u časopisima, almanasima ili kalendarima ostatku zajednice naziva poluusmenost (semi-oral process). Oba procesa

\footnotetext{
${ }^{10}$ Podatci Stjepana Krivošića o postotku nepismenih za prostor sjeverne Hrvatske pokazuju poražavajuće stanje: u 18. stoljeću, oko 1785. godine, nepismenih je bilo približno 93,5\% starijih od šest godina, a u 19. stoljeću, po podatcima za 1869 . godinu, bilo je $80,4 \%$ nepismenih starijih od šest godina $(74,4 \%$ muškaraca i 89,6\% žena) (vidi Stipčević 2005: 342-343). O postotku pismenih u ostalim zemljama Europe vidi Burke (1991: 198).

${ }^{11}$ Aleksandar Stipčević piše kako je skupno čitanje u prvoj polovici 20. stoljeća postalo oblikom "didaktičkog, prosvjetnog i ponajviše političkog rada". Ono je izgubilo čar književnoga domjenka i društvenoga komuniciranja koju je imalo u 19. stoljeću i stoljećima prije, kada su se u takvom obliku književne komunikacije slušatelji upoznavali s biblijskim pričama ili s Kačićevom pjesmaricom i različitim pučkim književnim tekstovima, a postalo je oblikom političke agitacije (čitanje političkih spisa braće Radić ili Manifesta Komunističke partije) (vidi Stipčević 2008: 310-311).
} 
stvaraju literarnu situaciju, situaciju u kojoj se posreduje literarna informacija, te pokazuju veze i isprepletanje usmenosti i pismenosti (Schenda 2007: 127).

Pučka književnost računa s čitateljevim predznanjem. Mnogi čitatelji/ slušatelji pučke književnosti nemaju prijašnje iskustvo čitanja jer su u književnome životu sudjelovali samo u u okviru iskustva usmene književnosti. Dakle, tradicija čitanja na koju bi se mogli pozivati ne postoji, ali postoji bogata književna tradicija koja ih je oblikovala i u kojoj su aktivno sudjelovali - usmena književnost. Iz te specifičnosti proizlazi kako je pučki književni tekst namijenjen jednako uhu kao i oku jer se unutar slabopismene ili nepismene zajednice prima isključivo slušanjem (jedna osoba glasno čita maloj zajednici), a tu vezu teksta i glasa potvrđuju mnogi tekstovi pučke književnosti. Na vezu pismenosti i usmenosti upozorava Schenda (2007: 131-132) ističući kako je taj odnos uvjetovao i stil i daljnji prijenos tekstova. Chartier (2002) navodi francusku pučku produkciju, tzv. Bibliothèque Bleue, kao primjer povezanosti teksta i glasa (zvuka), odnosno pismenosti i usmenosti te transformacijâ teksta prilikom prilagodbe usmenoj recepciji. Vezanost uz usmenost uvjetuje podčinjavanje teksta zahtjevima usmenoga izvođenja jer se tekst i dalje čuva u pamćenju (njegova pismena materijalizacija nije dostupna svima i tek je jedan vid njegova postojanja).

Prepletanje usmenosti i pismenosti može se, pokazuje Chartier, očitovati na dva osnovna načina: prvo, preuzimanjem formula i motiva iz usmene književnosti kako bi se doprlo do ciljane publike, gdje je usmeno prisutno u pisanome kao oblik "plagiranja usmenosti"; drugo, glasnim čitanjem jer mnoštvo čitatelja tekst može razumjeti jedino posredovanjem glasa (vidi Chartier 2002: 55-56). Pučki pisci posežu za ustaljenim formama, ponavljanjima prepoznatljivih motiva, poznatim slikama kako bi preko dobro poznatih obrazaca, uglavnom iz usmene tradicije, ali i iz ranije pisane pučke tradicije, doprli do čitatelja i ponudili im, u njima poznatoj i prihvatljivoj formi, nove, poučne i zabavne sadržaje. ${ }^{12}$

\section{Pučki čitatelj i pučko čitanje}

Recipijenti se pučke književnosti razlikuju od recipijenata umjetničke književnosti prije svega po tome kako pristupaju tekstu, ali i prema tome kako se na njih kao čitatelje računa (Pavličić 1991). Široki društveni i kulturni slojevi čitatelja/slušatelja uživaju u ostvarenjima pučke književnosti jer im ona nudi ona iskustva koja su im potrebna i koja mogu prihvatiti i razumjeti, odnosno

\footnotetext{
${ }^{12}$ Botica (1998a) pokazuje kako su i Grabovac i Kačić kao vrsni pučki pisci crpili iz usmene književnosti koju su dobro poznavali i oni i njihovi recipijenti, a oslanjanje na poetiku tradicionalne usmene epike, kao i mjesta udaljavanja od tradicionalnoga epskoga stila, Davor Dukić (1998) vidi kao važno mjesto Grabovčeva teksta.
} 
ono što je razumljivo iz iskustva svakodnevnoga života, što se oslanja na kodove svakodnevice (Solar 1995: 103, 136; Bošković-Stulli 1983: 55-56). Da bi uživao u tim književnim ostvarenjima, čitatelj ne mora imati iskustvo čitanja "visoke" književnosti niti stupanj obrazovanja koji bi mu osigurao predznanje potrebno za razumijevanje "visoke" književnosti. On u književnosti traži poznata iskustva, razumljiva iz svakodnevnoga života, teme koje pružaju mogućnost emocionalnoga uživljavanja, pouku i zabavu.

Potencijal pučkosti leži u načinu čitanja teksta. Za pristup pučkoj književnosti vrlo je poticajna Katičićeva argumentacija o mogućnosti čitanja tekstova kao književnih i neknjiževnih (Katičić 1971: 228). Svaki se književni tekst može čitati pučki, ali neki tekstovi imaju u sebi pučki potencijal koji se realizira u načinu čitanja teksta, u pristupu tekstu. Mnogi tekstovi umjetničke književnosti ulaze u sferu pučkoga, čitaju se kao pučki i prilagođavaju zahtjevima pučke poetike. Pritom je važna mogućnost emocionalnoga uživljavanja čitatelja. Zato će u sferu pučke književnosti najlakše ulaziti tekstovi snažnih emocija, senzacionalnih i čudnih događaja, domoljubni stihovi i priče o nesretnim ljubavima.

Pučki čitatelj i obrazovani čitatelj različito čitaju književni tekst, polaze iz različitih pozicija, različitoga predznanja i s različitim očekivanjima. Njihovi se horizonti očekivanja razlikuju kao što se razlikuje i njihovo doživljavanje književnosti. Pučko je čitanje orijentirano na sadržajni sloj djela, čitatelj zahtijeva priču koju može razumjeti, a manje ga zanima kako je priča ispričana (vidi Pavličić 1991: 88; Zečević 1978: 361). Pučke su knjige, tzv. chapbooks i broadside ballads, svojim sadržajima orijentirane upravo na pučkoga čitatelja željnoga senzacionalnih događaja. Chapbooks su sadržavale senzacionalne priče, prozne i/ili stihovane opise smaknuća, sve uz ilustracije koje su uz priču nudile multimedijalno iskustvo, a prednost pričama o nasilnim ubojstvima i smaknućima davale su i vrlo popularne pučke balade (eng. broadside ballads) (vidi Eliot 2009: 295). ${ }^{13}$

Pavličićevo pregledno uspoređivanje osobina pučkoga čitatelja i čitatelja umjetničke književnosti pokazuje i kakav status pučka književnost ima u odnosu na središnju, umjetničku književnost. Ako nekritički pristupimo pučkoj književnosti i promatramo je isključivo iz vizure i vrednovanja umjetničke književnosti, nameće nam se sud o pučkoj književnosti kao bezvrijednoj ili, kako je to naveo Jauss, kao o tipu kulinarske umjetnosti, zabavne književnosti koja unaprijed odustaje od književnih ambicija. Poslužimo li se Jaussovim terminom, estetska je udaljenost između čitateljeva očekivanja i očekivanja koja je postavio tekst mala jer tekst u potpunosti zadovoljava očekivanja

${ }^{13}$ Pučke su knjižice svojim čitateljima/slušateljima nudile iskustva koja danas pružaju sapunice i reality šouovi. Ti su televizijski žanrovi, tipični proizvodi popularne kulture, i svojom formom slični pučkim tekstovima (vidi Nemec 2006: 156-158). 
svoje publike ne zahtijevajući od nje veća prilagođavanja. Možemo reći kako pučki književni tekstovi, zadovoljavajući unaprijed očekivanja svojih čitatelja, postoje kao čitljivi tekstovi (Barthes) ${ }^{14}$ jer ne zahtijevaju čitateljsku aktivnost niti omogućuju preustroj čitateljeve svijesti. Međutim, odrednica pučkih tekstova kao čitljivih nije nužno i vrijednosni kriterij, nego više pokazuje njihov "klasični" status/karakter. Oni uvjetuju, a ujedno su i uvjetovani, odnosom prema recipijentu.

U odnosu na čitatelja umjetničke književnosti, pučki čitatelj/slušatelj djeluje pasivno. Međutim, aktivnost pučkoga recipijenta prisutna je u njegovoj "autorskoj" poziciji baštinjenoj iz tradicionalne usmenoknjiževne komunikacije. Budući da se pučki tekstovi, osobito stihovani oblici, prenose i usmenim putem, oslabljena je pozicija autora u pučkoj književnosti te kao i u usmenoj situaciji, čitatelj/slušatelj potencijalni je novi ko-autor. On tako zadržava dio svoje baštinjene aktivnosti koja podrazumijeva njegovu uključenost u proces proizvodnje teksta i značenja.

Spoznajna dimenzija pučke književnosti leži u njezinoj potrebi da suoči čitatelja s njegovim vlastitim vrijednostima i mogućnostima neprestano ukazujući na svijet i poredak stvari kakav bi trebao biti. Pučki književni tekst nije izazov po svojoj konstrukciji i jezičnome sastavu, nego njegov izazovni potencijal leži u sadržaju. Izazov čitatelju nalazi se u susretu s idejama i razmišljanjima koja su često suprotna ustaljenim praksama. Tomu je tako prije svega jer pučka književnost ima jasnu predodžbu svojega čitatelja, njegovih književnih potreba i želja, njegovih mogućnosti te mu nudi sadržaj oblikovan na njemu prihvatljiv način, najčešće ugledanjem na jezik i stil usmene književnosti. Ustupak čitatelju puno je veći na izraznome nego na sadržajnome planu. Ne znači, naravno, da je svaki pučki književni tekst na svojoj sadržajnoj, tematskoj i/ili sižejnoj razini izazov recipijentu. Kao i unutar sustava umjetničke književnosti, i unutar pučke književnosti imamo uspješna i manje uspješna ostvarenja. Uspješni će tekstovi poticati recipijentsku aktivnost i širenje njihova spoznajnoga svijeta nudeći duhovnu i kulturnu nadgradnju, što u slučaju pučke književnosti znači i podržavanje tradicionalnoga poretka, odnosno skrb za tradicionalne vrijednosti zajednice (od lokalne zajednice do šire nacionalne).

${ }^{14} \mathrm{U}$ studiji S/Z (1974) Barthes razlikuje tzv. čitljive tekstove (fra. lisible, eng. readerly) i ispisive tekstove (fra. scriptible, eng. writerly). Čitljivi tekst je, kako kaže Barthes, klasični tekst, relativno zatvoren, pristupačan i jednostavan za čitanje, on zahtijeva u osnovi pasivnoga čitatelja koji prihvaća značenja teksta kao unaprijed dana te kao takav ne iziskuje dodatnu čitateljsku aktivnost u proizvodnji značenja. Ispisivi tekst je otvoren, polisemičan i dijalogičan, zahtijeva aktivnoga čitatelja koji sudjeluje u procesu stvaranja značenja te je kao takav složeniji od čitljivoga teksta (Barthes 1974). 


\section{Subverzivna snaga pučkoga: pučko kao otpor}

Potreba da se ponuđenim sadržajima djeluje na prosvjećivanje puka, odabranoga čitateljskoga i slušateljskoga sloja, podrazumijeva selekciju sadržaja. Pučkomu čitatelju bit će ponuđeni sadržaji koji mu mogu biti korisni i ugodni, koji zadovoljavaju njegove potrebe. Uz pitanje tko procjenjuje koje su to potrebe puka i koje bi mu tekstove trebalo ponuditi, a uz pretpostavku da te procjene u pravilu dolaze "odozgo", iz pozicije moći i osiguravaju zadržavanje kontrolne pozicije, postavljamo i pitanje o mogućemu podcjenjivanju čitateljeve mogućnosti razumijevanja teksta.

Ako uzmemo u obzir da je pučka knjiga od 18. stoljeća dijelom šire društvene propagande opismenjavanja i prosvjećivanja puka, dijelom i političkoga djelovanja kojim se osiguravala kontrola puka, jasno je zašto su odabirani sadržaji koje je obrazovani sloj mogao doživjeti trivijalnima, ali isto tako i pogodnima za širenje određenih ideja. Unutar projekta tzv. popularnoga prosvjetiteljstva, koje je u Europi u 18. stoljeću zauzelo maha, i pokušaja djelovanja na neobrazovanu i polupismenu masu, knjiga za puk odigrala je važnu ulogu. Moglo se odabirom prikladnih i potrebnih sadržaja kontrolirati prosvjećivanje puka jer, kako to pokazuje Knudsen, cilj nije bio učiniti masu preobrazovanom, samomislećom silom koju je teško kontrolirati (vidi Knudsen 1996: 275). Kolikogod se, međutim, činilo da je kontrola puka preko ponuđenih mu sadržaja jednostavna i djelotvorna, toliko se puk uvijek opire kontroli koja dolazi "odozgo" i neprestano je potkopava.

Na mogućnost takozvane "zablude o recepciji" (eng. the receptive fallacy) upozorava Jonathan Rose (2002) i navodi kako je jedna od osnovnih zabluda pretpostavka da obični čitatelj čita tekst onako kako je to autor ili priređivač zamislio, odnosno da poruka koju je autor "stavio" u tekst nužno dolazi do čitatelja. Čitanje se kao proces ne može potpuno kontrolirati te se onda ne može kontrolirati ni učinak teksta na običnoga čitatelja. Rose navodi kako ni propagandni tekstovi koji su bili namijenjeni običnomu čitatelju nisu uvijek polučili željen učinak (vidi Rose 2002: 334), a na mogućnost zablude o pasivnome prihvaćanju ideja iznesenih u pučkim tekstovima upozorava i Peter Burke (1991: 67-69).

Puk je pronašao način svojevrsnoga otpora vlasti i vladajućoj ideologiji, razvio je vlastite taktike otpora u neprihvaćanju vlašću ovjerovljenih svjetonazorskih koncepcija (vidi Bahtin 1978; de Certeau 2003; Rudan Kapec 2010: 79-84).

Michel de Certeau (2003) upozorava na snagu društvenih djelatnih praksi, takozvanih taktika, ${ }^{15}$ koje izmiču kontroli vladajućih struktura. Životna je

${ }^{15}$ De Certeau razlikuje strategije i taktike kao dva načina društvenih djelatnih praksi. Strategije su prakse vladajućega poretka, a pod njima de Certeau podrazumijeva "računanje (ili manipulaciju) $s$ odnosom snaga koje postaje moguće od trenutka kada se dade izdvojiti jedan subjekt volje i moći (podu- 
svakodnevica prepuna praksi otpora kojima se potkopava moć vladajućih poredaka jer se svakodnevni život "izumljuje tisućama načina prekoračivanja dopuštenog" (de Certeau 2003: 32). Prakse otpora unutar podređenih klasa Bahtin (1978) vidi u narodnoj smjehovnoj kulturi srednjega vijeka i renesanse, u karnevalizaciji svijeta koja je osigurala "privremeno oslobađanje od vladajuće istine i postojećeg poretka, privremeno ukidanje svih hijerarhijskih odnosa, privilegija, normi i zabrana" (Bahtin 1978: 16). Pojedine svakodnevne prakse pučke kulture možemo također promatrati kao potkopavanje strategija dominantne, vladajuće paradigme uz napomenu da je u tome susretu kultura utjecaj obostran, a prožimanja "male" i "velike" tradicije (ili podređene i dominantne kulture) neizbježna i produktivna.

Vrlo komunikativna forma ulične literature ${ }^{16}$ bio je letak koji je funkcionirao kao sredstvo informiranja "odozgo", predstavljao je način plasiranja informacija puku, ali je i puk nerijetko koristio ista sredstva kako bi pokazao svoj otpor prema nametnutim idejama, osobito u onim prostorima gdje je letak imao dugu tradiciju. ${ }^{17} \mathrm{U}$ gorljivim i angažiranim stihovima tiskanima u obliku letaka, pamfleta ili pučkih pjesama i lijepljenima po stupovima i zidovima, pučki su pjesnici progovarali protiv lokalnih vođa i njihove tiranije (vidi Zečević 1978: 403). Uz vrlo česte pohvalne stihove, hvalospjeve gospodi i iskaze odanosti kruni (vladajućima), letci su donosili i stihove pune ironije, snažnu satiru i kritiku društva i egzistencijalnih prilika onoga vremena (Lukežić 2007: 14). Puk je svoj otpor, ili još češće svoje nezadovoljstvo i apsurd političke situacije, uspio izraziti i pučkim deseteračkim dvostihovima, ironizirajućim iskazima društveno-političke situacije. ${ }^{18}$

zeće, vojska, grad, znanstvena ustanova). Ona (strategija) ustanovljuje mjesto koje se može odrediti kao vlastito i biti osnovom s koje se može upravljati odnosima s izvanjskošću sastavljenom od meta ili prijetnji (mušterije ili konkurenti, neprijatelji, selo u okolici grada, ciljevi i predmeti istraživanja itd.)" (2003: 88). Na tom strateškom obrascu nastale su brojne strukture moći. Taktikama de Certeau naziva djelatne prakse životnoga svagdana koje izmiču kontroli vladajućih poredaka. Njihovo je obilježje pokretljivost, trenutnost, odsutnost vlastitoga mjesta. Taktika je "umijeće slaboga", određena je "odsutnošću moći", a njezino jedino mjesto jest "mjesto drugoga". Taktika postoji u vremenu i ovisna je o njemu "kako bi u letu uhvatila mogućnosti što ih pruža trenutak" (vidi de Certeau 2003: 40, 86-95).

${ }^{16}$ Ulična je literatura veliku snagu otpora i protesta imala u prvim stoljećima svojega pojavljivanja kada je propagandno djelovanje bilo ciljano. Leslie Shepard (1973:125-127) donosi podatak da već u 19. stoljeću ulične balade gube svoju "militantnu" snagu, tiskaju se za novac i podređuju zakonima tržišta te propaganda ustupa mjesto zabavi. Ti se procesi na hrvatskoj književnoj sceni događaju tek krajem 19. i u prvim desetljećima 20. stoljeća kada dolazi do pravoga širenja čitateljske publike i razvoja književnoga tržišta.

${ }^{17}$ U Hrvatskoj letak nema dugu tradiciju kao u ostalim europskim zemljama (primjerice Engleskoj, Njemačkoj, Italiji, Francuskoj) te je njegova snaga "protestne literature" puno manja. Puno su veću komunikativnu snagu na hrvatskim prostorima ostvarile usmeno prenošene pučke pjesme. Više o toj problematici u Botica (1998b: 25-26).

${ }^{18}$ Upravo su ti pučki stihovi, kao odraz zdravorazumskih stavova "maloga” čovjeka, privukli i Miroslava Krležu koji simpatiju prema pučkoj političkoj lirici, političkim rugalicama punima ironije, sarkazma i gorčine pokazuje u Davnim danima (Krleža 1956: 356). Krleža je u toj lirici vidio bistrinu narodnoga duha, bunt, izostanak mitologizacije, stvarnost kako je vidi puk, on "iskazuje ovdje prisno razumijevanje za autentično književno-jezično stvaranje puka" (Bošković-Stulli 1984: 35). 


\section{PREMA ZAKLJUČKU}

Pučku se književnost često određuje kao kulinarsku (ne)umjetnost, lošu književnost koja "sluša" zahtjeve široke čitateljske publike i time se ogrešuje o zakone prave (misleći pritom "visoke", pisane umjetničke) književnosti. Zaboravlja se pritom da je u pučkoj književnosti komunikacija između autora i recipijenta puno dinamičnija. Zahtjevi ne idu samo od recipijenta prema autoru, nego jednako i od autora prema recipijentu. Jednako pisac oblikuje (poučava) svoju publiku, kao što publika svojim zahtjevima oblikuje djelo/tekst. Pučku književnost karakterizira postignut sklad između pisca i publike kojoj se obraća. Obostranost tih utjecaja zrcali i Horacijeva maksima prodesse et delectare koja je primjenjiva na pučku književnost. Pučka književnost afirmira oba pojma iz Horacijeve maksime, uspješno spaja pouku i zabavu ostajući tako u domeni "praktičnosti" s naglašenom izvanknjiževnom funkcijom, uz važnu napomenu da pučka poučnost uključuje zabavu kojom se otvara mogućnost uživanja u tekstu - pouka je rezultat prosvjetiteljske orijentacije pisca, a zabava odgovor na zahtjeve recipijenta.

Razumijevanje pučkih recipijenta, njihovih estetskih očekivanja i načina čitanja teksta otkriva gradbenu strukturu pučkih tekstova. Pučka književnost računa na čitateljsko/slušateljsko predznanje, na različite čitateljske sposobnosti i razinu estetske kondicioniranosti s kojom raspolažu te pomno bira izraz prihvatljiv doživljajno-spoznajnim mogućnostima recipijenata i njihovim estetskim zahtjevima. To je unutar pučkih izdanja značilo prilagodbu tekstova koja je obuhvaćala kraćenje, pojednostavljivanje, rezanje i ilustriranje, kako bi im se osigurala prihvaćenost unutar širih slojeva.

Koncepti autorstva i originalnosti koji su u osnovi modernoga shvaćanja književnosti nisu važna uporišna mjesta pučke književnosti. Slabljenje autorske pozicije u odnosu na poziciju autora u pisanoj umjetničkoj književnosti znači da ni autor ni tekst ne mogu biti jedina polazišta za razumijevanje pučke poetike, stoga preciznije definiranje pučkoga književnoga fenomena mora uključiti pučkoga recipijenta kao najvažniju sastavnicu (pučko)književne komunikacije.

Razlaganje o recipijentima pučke književnosti, društvenoj strukturi pučkoga čitateljskoga/slušateljskoga sloja i mehanizmima recepcije pokazalo je da se preko recipijenata može najbolje razumjeti i definirati pučka poetika. Iz specifičnosti pučkoga čitateljstva proizlaze specifičnosti pučke književnosti i njezine poetičke zakonitosti, ili riječima Marine Protrka "percepcija potencijalnoga čitatelja definira i vrstu estetike" (2008: 73). Pučka je poetika, kako se pokazuje iz analize, prepoznatljiva komunikacijski i kontekstualno, odnosno pučkost se očituje u odnosu teksta i recipijenta, u načinu na koji se pristupa tekstu. 


\section{NAVEDENA LITERATURA I IZVORI}

Bahtin, Mihail. 1978. Stvaralaštvo Fransoa Rablea i narodna kultura srednjega veka i renesanse. Beograd: Nolit.

Barthes, Roland. 1974. S/Z. New York: Hill and Wang.

Bošković-Stulli, Maja. 1983. "O pojmovima usmena i pučka književnost i njihovim nazivima”. U Usmena književnost nekad i danas. Beograd: Prosveta, 5-114.

Bošković-Stulli, Maja. 1984. "Usmeno pjesništvo u Krležinu obzorju”. U Usmeno pjesništvo u obzorju književnosti. Zagreb: Nakladni zavod Matice hrvatske, 7-68.

Botica, Stipe. 1998a. "Grabovčevo djelo u suodnosu s usmenom/pučkom književnosti i Kačićem". U Fra Filip Grabovac u kontekstu hrvatske kulture. Neven Strukan, ur. Vrlika: Poglavarstvo grada Vrlike, Matica hrvatska Vrlika, Matica hrvatska Sinj, 103-111.

Botica, Stipe. 1998b. Lijepa naša baština. Književno-antropološke teme. Zagreb: Hrvatska sveučilišna naklada.

Burke, Peter. 1991. Junaci, nitkovi i lude. Narodne kultura predindustrijske Evrope. Zagreb: Školska knjiga.

De Certeau, Michel. 2003. Invencija svakodnevice. Zagreb: Naklada MD.

Chartier, Roger. 2002. "Labourers and Voyagers: From the Text to the Reader". U The Book History Reader. David Finkelstein i Alistair McCleery, ur. New York, London: Routledge, 47-58.

Crnković, Nikola. 2003. Paška pučka poetika kao povijestni govor. Zagreb, Novalja: Denona.

Crnković, Nikola. 2011. Pažka pučka poetika kao povijestni govor. Kolan i Novalja, 1. Novalja: Grad Novalja i Matica hrvatska - ogranak Novalja.

Dukić, Davor. 1998. “Grabovčev Cvit razgovora i usmenoepska tradicija”. U Fra Filip Grabovac u kontekstu hrvatske kulture. Neven Strukan, ur. Vrlika: Poglavarstvo grada Vrlike, Matica hrvatska Vrlika, Matica hrvatska Sinj, 113-121.

Eliot, Simon. 2009. "From Few and Expensive to Many and Cheap. The British Book Market 1800-1890". U A Companion to the History of the Book. Simon Eliot i Jonathan Rose, ur. Malden, Oxford, Chichester: Wiley-Blackwell, 291-302.

Jolles, Andre. 2000. Jednostavni oblici. Zagreb: Matica hrvatska.

Katičić, Radoslav. 1971. Jezikoslovni ogledi. Zagreb: Školska knjiga.

Kekez, Josip. 1998. "Usmena književnost”. U Uvod u književnost. Teorija, metodologija [5. poboljšano izdanje]. Zdenko Škreb i Ante Stamać, ur. Zagreb: Nakladni zavod Globus, 133192.

Knudsen, Jonathan B. 1996. “On Enlightenment of the Common Man”. U What is Enlightenment? Eighteenth-century Answers and Twentieth-century Questions. James Schmidt, ur. Berkeley, Los Angeles: University of California Press, 270-290.

Krleža, Miroslav. 1956. Davni dani. Zapisi 1914 - 1921. Zagreb: Zora.

Lukežić, Irvin. 2007. "Riječki letak kao oblik učene i pučke književne tradicije”. Fluminensia 19/1: 13-34.

Matić, Tomo. 1951. "Motiv Olive u starijoj hrvatskoj književnosti”. U Građa za povijest književnosti hrvatske, 21. Antun Barac, ur. Zagreb: Jugoslavenska akademija znanosti i umjetnosti, 143-219.

Matić, Tomo. 1994. Prosvjetni i književni rad u Slavoniji prije preporoda (odabrana poglavlja). Slavonsko selo u djelima hrvatskih pisaca potkraj osamnaestoga vijeka, Ivo Bogner, prir. Vinkovci: Slavonska naklada Privlačica. 
Nemec, Krešimir. 2006. "Od feljtonskih romana i 'sveščića' do sapunica i Big Brothera”. U Raslojavanje jezika i književnosti. Zbornik radova 34. seminara Zagrebačke slavističke škole. Krešimir Bagić, ur. Zagreb: FF press, 143-158.

Pavličić, Pavao. 1987a. "Divna Zečević, Književnost na svakom koraku, Studije i članci, Mala teorijska biblioteka 20, Izdavački centar 'Revija', Radničko sveučilište 'Božidar Maslarić', Osijek 1986, 268 str.". Narodna umjetnost 24/1: 248-249.

Pavličić, Pavao. 1987b. "Pučka, trivijalna i masovna književnost”. U Trivijalna književnost. Svetlana Slapšak, ur. Beograd: Studentski izdavački centar UK SSO, Institut za književnost i umetnost, 73-83.

Pavličić, Pavao. 1991. “Kamo pripada Reljkovićev Satir?” U Vrijeme i djelo Matije Antuna Reljkovića: znanstveni skup, Nova Gradiška 25.-27. listopada 1984. Dragutin Tadijanović i Josip Vončina, ur. Osijek: Jugoslavenska akademija znanosti i umjetnosti, 85-94.

Protrka, Marina. 2008. Stvaranje književne nacije. Oblikovanje kanona u hrvatskoj književnoj periodici 19. stoljeća. Zagreb: FF Press.

Rose, Jonathan. 2002. "Rereading the English Common Reader. A Preface to a History of Audiences". U The Book History Reader. David Finkelstein i Alistair McCleery, ur. New York, London: Routledge, 324-339.

Rudan Kapec, Evelina. 2010. "Nadnaravna bića i pojave u predajama u Istri". [Doktorska disertacija]. Zagreb: Filozofski fakultet Sveučilišta u Zagrebu.

Schenda, Rudolf. 2007. "Semiliterate and Semi-Oral Processes". Marveles \& Tales 21/1: 127140.

Shepard, Leslie. 1973. The History of Street Literature. The Story of Broadside Ballads, Chapbooks, Proclamations, News-Sheets, Election Bills, Tracts, Pamphlets, Cocks, Catchpennies, and other Ephemera. Newton Abbot: David \& Charles.

Slamnig, Ivan. 1965. Disciplina mašte. Zagreb: Matica hrvatska.

Solar, Milivoj. 1995. Laka i teška književnost. Predavanja o postmodernizmu i trivijalnoj književnosti. Zagreb: Matica hrvatska.

Stipčević, Aleksandar. 2005. Socijalna povijest knjige u Hrvata, 2. Od glagoljskog prvotiska (1483) do hrvatskoga narodnog preporoda (1835). Zagreb: Školska knjiga.

Stipčević, Aleksandar. 2008. Socijalna povijest knjige u Hrvata, 3. Od početka hrvatskoga narodnog preporoda (1835.) do danas. Zagreb: Školska knjiga.

Tatarin, Milovan. 1999. Zaboravljena Oliva. Zagreb: Matica hrvatska.

Tatarin, Milovan. 2006. "Uloga pučkih kalendara u stvaranju hrvatske čitateljske publike (Kalendar Ignjata Alojzija Brlića)”. U Raslojavanje jezika i književnosti, Zbornik radova 34. Seminara Zagrebačke slavističke škole. Krešimir Bagić, ur. Zagreb: FF press, 107-141.

Tatarin, Milovan. 2007. “Jedan zaboravljeni slavonski kalendar iz 18. stoljeća”. U Dani Hvarskoga kazališta 33. Prešućeno, zabranjeno, izazovno u hrvatskoj književnosti i kazalištu. Nikola Batušić i dr., ur. Zagreb i Split: Hrvatska akademija znanosti i umjetnosti, Književni krug Split, 131-185.

Tomašić Jurić, Josipa. 2014. "Pučka sastavnica u djelu Luke Ilića Oriovčanina”. [Doktorska disertacija]. Zagreb: Filozofski fakultet Sveučilišta u Zagrebu.

Zečević, Divna. 1971. "Rastvaranje formula tradicionalne usmene poezije - formule pučkih pjesama”. Narodna umjetnost 8/1: 19-41.

Zečević, Divna. 1978. "Pučki književni fenomen”. U Maja Bošković-Stulli i Divna Zečević. Povijest hrvatske književnosti, 1. Usmena i pučka književnost. Zagreb: Liber, Mladost, 357-638.

Zečević, Divna. 1982. Pučko književno štivo u hrvatskim kalendarima prve polovice 19. stoljeća, 1. Osijek: Izdavački centar Revija, Radničko sveučilište Božidar Maslarić Osijek, RO “Zagreb”. 
Zečević, Divna. 1986. Književnost na svakom koraku (Studije i članci). Osijek: Izdavački centar Revija, Radničko sveučilište Božidar Maslarić Osijek.

Zečević, Divna. 1988. Hrvatske pučke pjesmarice 19. stoljeća (Svjetovne i nabožne). Osijek: Izdavački centar Revija, Radničko sveučilište Božidar Maslarić Osijek.

Zečević, Divna. 1991. Prošlost u sadašnjosti. Popularnost pučkog književnog mišljenja. Osijek: Izdavački centar Revija Otvorenog sveučilišta Osijek.

Zečević, Divna. 1993. Strah Božji. Hrvatske pučke propovijedi 18. stoljeća. Osijek, Zagreb: Izdavački centar Revija Otvorenog sveučilišta Osijek, Institut za etnologiju i folkloristiku.

\title{
RECIPIENTS OF POPULAR LITERATURE AS A STARTING POINT FOR THE UNDERSTANDING OF POPULAR POETICS
}

\author{
SUMMARY
}

This paper problematizes the phenomenon of popular literature with reference to the recipients of popular literature. Our initial thesis is that what is considered as popular is not contained in the text itself, but in the manner the text is approached. We observe the social structure of the popular reader/listener, his/her aesthetic demands, which define the structure and the aesthetics of the popular literary text. We observe popular literature within the previous research of Croatian popular literature with a focus on the prolific work of Divna Zečević, which sets the foundation for further systematic research on the popular literary phenomenon.

Keywords: popular literature, recipient, popular text, chapbooks, popular enlightenment 